\title{
EFEKTIVITAS MODEL PEMBELAJARAN KOOPERATIF TIPE THINK TALK WRITE (TTW) TERHADAP KEMAMPUAN KOMUNIKASI MATEMATIKA SISWA KELAS VIII MTs NEGERI GODEAN
}

\author{
Fety Risdiyati ${ }^{1)}$, Sri Endah Mianti'i ${ }^{2}$, Laela Sagita ${ }^{3)}$ \\ ${ }^{1}$ MTs Negeri Godean \\ risdi.fety@gmail.com \\ ${ }^{2,3}$ FKIP Universitas PGRI Yogyakarta \\ sri.endahmianty@gmail.com \\ sagita.laela@gmail.com
}

\begin{abstract}
The research aims to determine the effectiveness of cooperative learning model type Think Talk Write (TTW) and type Think Pair Share (TPS) toward the mathematic communication skill students of grade $8^{\text {th }}$ in MTs $N$ Godean.

This type of research is comparative descriptive which aplies Pretest Posttest Control Group Design. An instrument used in this study there are two kinds of the instruments learning and instruments data collection. An instrument consisting of learning implementation lesson plans and sheets of student activity, instruments gather data consists of broad observation, questionnaire, a test (pretest and posttest) and documentation. Analysis of data on research use t test some help software Ms. Excel 2010 and SPSS 20.

The results of research pretest and posttest show that experiment class with cooperative model type Think Talk Write (TTW) and control class with cooperative model type Think Pair Share (TPS) normal distribution, both classes are homogenous and both classes have the same initial capability. The cooperative learning model type Think Talk Write (TTW) is same effective with cooperative learning model type Think Pair Share (TPS) toward the mathematic communication skill students. The level of effectiveness cooperative learning model type Think Talk Write (TTW) is 0,30 with medium category and the level of effectiveness cooperative learning model type Think Pair Share (TPS) is 0,28 with low category. Cooperative learning model type Think Talk Write (TTW) is same effective with cooperative learning model type Think Pair Share (TPS) because the students are individually active role in group discussions and there is the same syntax for these two models namely stage think.
\end{abstract}

Keyword: Cooperative learning model type Think Talk Write (TTW), cooperative learning model type Think Pair Share (TPS), mathematic communication skill students.

\section{PENDAHULUAN}

Berdasarkan observasi yang dilakukan di MTs Negeri Godean khususnya kelas VIII, kemampuan komunikasi matematika siswa masih tergolong relatif rendah. Hal ini ditunjukkan pada saat proses pembelajaran matematika berlangsung siswa masih sulit untuk menginterpretasikan ke dalam bentuk simbol matematika, membuat model matematika, menjelaskan ide matematika secara tertulis, kemudian ketika guru memberikan soal yang menuntut kemampuan siswa dalam hal menggambar masih banyak siswa yang masih membutuhkan bantuan guru, siswa masih banyak bimbingan ketika mengerjakan 
Efektivitas Model Pembelajaran Kooperatif Tipe Think Talk Write (TTW)

Terhadap Kemampuan Komunikasi Matematika Siswa Kelas VIII MTs Negeri

Godean

Fety Risdiyati, Sri Endah Mianti, Laela Sagita

soal sehingga ketika dicocokan banyak matematika merupakan suatu peristiwa jawaban benar. Selain itu, siswa masih kesulitan untuk mengungkapkan kembali atau membuat kesimpulan menggunakan bahasa sendiri. Hal ini membuktikan bahwa kemampuan komunikasi matematika siswa di kelas VIII masih kurang baik.

Pada observasi ini, peneliti memberikan soal pretest untuk mengukur kemampuan komunikasi matematika siswa kelas VIII. Hasil pretest yang telah dilakukan peneliti terhadap kelas VIII MTs Negeri Godean yang terdiri atas 4 kelas yaitu VIII A, VIII B, VIII C, VIII D adalah sebagai berikut.

Tabel 1. Rata-rata skor tiap indikator kemampuan komunikasi matematika siswa secara tertulis

\begin{tabular}{|l|c|c|c|c|}
\hline \multirow{2}{*}{ Kelas } \\
VIIIA-VIIID & \multicolumn{4}{|c|}{ Indikator } \\
\cline { 2 - 5 } & 1 & 2 & 3 & 4 \\
\hline Rerata & 39,84 & 37,50 & 39,06 & 6,77 \\
\hline Persent. & $40 \%$ & $38 \%$ & $39 \%$ & $7 \%$ \\
\hline Kategori & KB & KB & KB & SK \\
\hline
\end{tabular}

Keterangan:

$$
\begin{array}{ll}
\text { KB } & =\text { Kurang Baik } \\
\text { SK } & =\text { Sangat Kurang }
\end{array}
$$

Berdasarkan tabel 1, terlihat bahwa kemampuan komunikasi matematika siswa kelas VIII MTs Negeri Godean masih tergolong kurang baik. Hal tersebut dapat dilihat berdasarkan kriteria untuk menafsirkan ketercapaian indikator kemampuan komunikasi matematika siswa. Ahmad Susanto (2013: 213) mengemukakan bahwa komunikasi dialog atau saling hubungan yang terjadi di lingkungan kelas, dimana terjadi pengalihan pesan dan pesan yang dialihkan berisikan tentang materi matematika yang dipelajari siswa, misalnya berupa konsep, rumus atau strategi penyelesaian suatu masalah. Komunikasi tersebut sangat dibutuhkan siswa untuk dapat berdialog satu sama lain dan menghubungkan pemahaman dirinya dengan siswa lain. Pendapat Ahmad Susanto tersebut sejalan dengan pendapat dari Rosliana Harahap (2012: 197) bahwa komunikasi matematika merupakan kemampuan siswa untuk menuliskan suatu ide/gagasan tertentu, menggambarkan diagram/grafik, membuat model matematika dan mengekspresikan model matematika ke bahasa verbal atau sebaliknya.

Komunikasi matematika dapat diukur dan dilihat secara langsung. Indikator yang menunjukkan komunikasi matematika antara lain.

a. Dapat membuat gambar, grafik atau diagram yang relevan dengan wacana matematika yang sedang dipelajari.

b. Dapat menjelaskan ide, situasi dan relasi matematika secara tertulis.

c. Dapat membuat model atas situasi atau persoalan secara tertulis 
Jurnal Derivat Volume 3 No. 1 juli 2016 (ISSN: 2407 - 3792)

Halaman 49 - 56

menggunakan simbol atau skema berpikir.

d. Dapat mengungkapkan kembali atau membuat kesimpulan secara tertulis menggunakan bahasa sendiri.

(Utari Sumarmo. 2005:7)

Berdasarkan ungkapan para ahli di atas, kemampuan komunikasi matematika sangatlah penting untuk dimiliki. Akan tetapi pada kenyataannya siswa masih belum memiliki kemampuan komunikasi yang baik. Hal tersebut dimungkinkan karena dalam proses pembelajaran di kelas yang belum maksimal. Masalahmasalah yang terjadi saat pembelajaran matematika harus diminimalisir dan dikreasikan dengan menggunakan pembelajaran yang baru. Salah satunya dengan model pembelajaran yang menekankan siswa untuk berperan aktif saat pembelajaran berlangsung. Model pembelajaran yang efektif untuk kemampuan komunikasi matematika. Salah satunya adalah model pembelajaran kooperatif tipe Think Talk Write (TTW).

Model pembelajaran kooperatif tipe Think Talk Write (TTW) merupakan suatu model pembelajaran yang belum diterapkan di MTs N Godean. Model pembelajaran kooperatif TTW ini dapat menumbuh kembangkan kemampuan komunikasi. Model pembelajaran kooperatif tipe Think Talk Write (TTW) merupakan salah satu tipe pembelajaran

kooperatif yang menekankan pada
kegiatan berpikir, menyusun, menguji, mereflesikan dan menuliskan ide-ide. Sehingga model pembelajaran ini membantu siswa terhadap kemampuan komunikasi matematika melalui tahap berpikir, berbicara dan menulis. Strategi yang diperkenalkan pertama kali oleh Huinker dan Laughlin tahun 1996 ini didasarkan pada pemahaman bahwa belajar adalah sebuah perilaku sosial. Model ini memiliki dasar pada kemampuan komunikasi dan merupakan model belajar yang memfasilitasi siswa dalam latihan berbahasa secara lisan dan menulis bahasa tersebut dengan lancar. Miftahul Huda (2013: 218) juga mengungkapkan bahwa siswa akan terbantu dengan pembelajaran yang menerapkan model TTW. Hal ini karena siswa difasilitasi secara penuh dalam berlatih berbahasa baik lisan maupun tulisan.

Model pembelajaran kooperatif tipe Think Talk Write (TTW) memiliki keunggulan yang perlu menjadi bahan pertimbangan dalam melaksanakan pembelajaran, dan untuk mengetahui keefektifan model pembelajaran kooperatif tipe Think Talk Write (TTW) terhadap kemampuan komunikasi matematika siswa kelas VIII MTs Negeri Godean, peneliti menggunakan model pembelajaran tersebut dalam pembelajaran. Sebagai pembanding 
Fety Risdiyati, Sri Endah Mianti, Laela Sagita peneliti menggunakan model yang berbeda, yaitu model pembelajaran kooperatif tipe Think Talk Write (TTW) untuk kelas uji coba atau kelas eksperimen, sedangkan model pembelajaran yang digunakan sebagai kelas kontrol adalah model pembelajaran kooperatif tipe Think Pair Share (TPS).

Oleh karena itu tujuan yang diharapkan dari penelitian ini adalah untuk mengetahui keefektifan model pembelajaran kooperatif tipe Think Talk Write (TTW) terhadap kemampuan komunikasi matematika siswa kelas VIII MTs Negeri Godean.

\section{METODE PENELITIAN}

Jenis penelitian yang digunakan adalah Penelitian Deskriptif Komparatif. Dimana jenis penelitian ini adalah membandingkan kedua jenis model pembelajaran kooperatif tipe Think Talk Write (TTW) dengan model pembelajaran kooperatif tipe Think Pair Share (TPS) yang dilaksanakan di kelas VIII A dan VIII B MTs Negeri Godean pada semester genap tahun ajaran 2015/2016 pada bulan Mei 2016. Desain penelitian yang akan digunakan dalam penelitian ini adalah Pretest-Posttest Control Group Design, yaitu sebagai berikut.

\begin{tabular}{|cccc|}
\hline $\mathrm{R}$ & $\mathrm{O}_{1}$ & $\mathrm{X}$ & $\mathrm{O}_{2}$ \\
$\mathrm{R}$ & $\mathrm{O}_{3}$ & $\mathrm{C}$ & $\mathrm{O}_{4}$ \\
\hline
\end{tabular}

Keterangan:

$\mathrm{R} \quad$ : dua kelompok yang dipilih secara random

$X$ : perlakuan terhadap kelas eksperimen menggunakan model pembelajaran kooperatif tipe Think Talk Write (TTW)

C : perlakuan terhadap kelas kontrol menggunakan model pembelajaran kooperatif tipe Think Pair Share (TPS)

$\mathrm{O}_{1}$ : pretest kelas eksperimen

$\mathrm{O}_{2}$ : pretest kelas kontrol

$\mathrm{O}_{3}$ : posttest kelas eksperimen

$\mathrm{O}_{4}$ : posttest kelas kontrol

Populasi dalam penelitian ini adalah siswa MTs Negeri Godean kelas VIII. Teknik yang digunakan untuk memperoleh sampel dalam penelitian ini adalah simple random sampling. Sampel dalam penelitian ini adalah siswa kelas VIII A sebagai kelas eksperimen diberi perlakuan menggunakan pembelajaran dengan Think-Talk-Write sedangkan dan siswa kelas VIII B sebagai kelas kontrol diberi perlakuan menggunakan pembelajaran dengan Think-Pair-Share.

\section{HASIL DAN PEMBAHASAN}

Sebelum melakukan penelitian, maka dilakukan dulu uji prasyarat terhadap dua kelas yang digunakan dalam penelitian. Uji prasyarat tersebut meliputi 
uji kemampuan awal siswa menggunakan uji t, uji normalitas menggunakan SPSS 20 dan uji homogenitas menggunakan uji F (Anova).

Data statistik nilai pretest dari masing-masing kelas disajikan dalam tabel berikut.

Tabel 2. Data Statistik Nilai Pretest Kelas Eksperimen dan Kelas Kontrol

\begin{tabular}{|c|c|c|}
\hline Statistik & Eksperimen & Kontrol \\
\hline Rata-Rata & 67,53 & 65,19 \\
\hline Nilai Tertinggi & 77,78 & 70,83 \\
\hline Nilai Terendah & 56,94 & 56,94 \\
\hline
\end{tabular}

Uji Normalitas diperoleh nilai sig. $=0,200>0,05$, sehingga $H_{0}$ diterima yang artinya nilai pretest pada kelas eksperimen berdistribusi normal. Sedangkan pada kelas kontrol nilai sig. = $0,117>0,05$, sehingga $H_{0}$ diterima yang artinya nilai pretest pada kelas kontrol berdistribusi normal. Uji homogenitas menggunakan uji $\mathrm{F}$ diperoleh nilai $\mathrm{F}_{\text {hitung }}=$ $3,732<\mathrm{F}_{\text {tabel }}=4,0068$ dan nilai sig. $=$ $0,058>0,05$ sehingga $H_{0}$ diterima yang artinya kedua kelas eksperimen dan kelas kontrol mempunyai variansi yang homogen.

Untuk mengetahui kemampuan awal dari masing-masing kelas, maka statistik uji yang digunakan adalah uji t. Hasil perhitungan ini dengan taraf nyata $5 \%$ dan $\mathrm{dk}=57$ maka harga $\mathrm{t}$ pada tabel adalah 2,30. Dari hasil perhitungan, diperoleh nilai $\mathrm{t}=1,932<2,30$ sehingga $\mathrm{H}_{0}$ diterima. Jadi, dapat disimpulkan bahwa kedua kelas memiliki kemampuan awal yang sama.

Setelah uji asumsi terpenuhi maka dilakukan pengujian hipotesis. Hipotesis dalam penelitian ini diuji dengan menggunakan uji t satu pihak kanan dan skor gain. Data statistik nilai posttest dari masing-masing kelas disajikan dalam tabel berikut.

Tabel 3. Data Statistik Nilai Posttest Kelas Eksperimen dan Kelas Kontrol

\begin{tabular}{|c|c|c|}
\hline Statistik & Eksperimen & Kontrol \\
\hline Rata-Rata & 77,17 & 75,27 \\
\hline Nilai Tertinggi & 87,10 & 66,67 \\
\hline Nilai Terendah & 84,95 & 63,44 \\
\hline \multicolumn{2}{|c|}{ Pembelajaran matematika dengan }
\end{tabular}

model Think-Talk-Write sama efektifnya dengan model Think-Pair-Share terhadap kemampuan komunikasi matematika siswa terlihat dari nilai rata-rata posttest kemampuan komunikasi matematika siswa. Dalam hal ini, hasil posttest dihitung secara statistik dengan menggunakan uji t satu pihak kanan. Secara umum, hasil perhitungan diperoleh dengan taraf nyata 5\% maka harga t pada tabel adalah 2,005. Dari proses perhitungan, hasil $t_{o b s}=1,333<$ $t_{(0,05)(54)}=2,005$, maka $H_{0}$ diterima (uji tidak signifikan). Artinya, nilai rata-rata posttest komunikasi matematika siswa menggunakan model pembelajaran kooperatif tipe TTW sama efektifnya dengan menggunakan model pembelajaran kooperatif tipe TPS. 
Efektivitas Model Pembelajaran Kooperatif Tipe Think Talk Write (TTW)

Terhadap Kemampuan Komunikasi Matematika Siswa Kelas VIII MTs Negeri

Godean

Fety Risdiyati, Sri Endah Mianti, Laela Sagita

Untuk melihat sejauh mana Pair-Share. Dalam pengamatan ini,

keefektifan model pembelajaran yang proses pembelajaran diamati oleh

digunakan, maka menggunakan rumus observer. Pengamatan dilaukan oleh

skor gain. Dalam perhitungannya, peneliti peneliti menggunakan lembar observasi

melakukan secara manual dengan bantuan yang berisi tentang catatan yang

Ms. Excel 2010.

1. Model pembelajaran kooperatif tipe

Think Talk Write (TTW)

$$
\begin{aligned}
<g> & =\frac{T_{1}{ }^{\prime}-T_{1}}{T_{\text {maks }}-T_{1}} \\
& =\frac{77,17-67,53}{100-67,53}=0,30
\end{aligned}
$$

Berdasarkan hasil perhitungan, keefektifan model pembelajaran kooperatif tipe Think Talk Write (TTW) sebesar 0,30 dengan kategori sedang.

2. Model pembelajaran kooperatif tipe Think Pair Share (TPS)

$<g>=\frac{T_{1}{ }^{\prime}-T_{1}}{T_{\text {maks }}-T_{1}}$

$$
=\frac{75,27-65,19}{100-65,19}=0,28
$$

Berdasarkan hasil perhitungan, keefektifan model pembelajaran kooperatif tipe Think Pair Share (TPS) sebesar 0,28 dengan kategori rendah.

\section{Analisis Keterlaksanaan Pembelajaran}

Model Think-Talk-Write dan Model Think-Pair-Share

Kegiatan observasi dilakukan untuk mengamati proses pembelajaran dengan model Think-Talk-Write dan model Thinkmenerangkan proses pembelajaran dengan model Think-Talk-Write dan model Think-Pair-Share. Data statistik hasil observasi keterlaksanaan pembelajaran dengan model Think-TalkWrite dan model Think-Pair-Share adalah sebagai berikut.

Tabel 4. Hasil Observasi Keterlaksanaan Pembelajaran

\begin{tabular}{|l|c|c|c|c|}
\hline Presentase (\%) & $\mathrm{X}$ & $\begin{array}{c}\text { Kate } \\
\text { gori }\end{array}$ & $\mathrm{Y}$ & $\begin{array}{c}\text { Kate } \\
\text { gori }\end{array}$ \\
\hline $\begin{array}{l}\text { Presentase } \\
\text { keterlaksanaan } \\
\text { pembelajaran } \\
\text { matematika } \\
\text { oleh guru }\end{array}$ & 100 & $\mathrm{ST}$ & 100 & $\mathrm{ST}$ \\
\hline $\begin{array}{l}\text { Presentase } \\
\text { keterlaksanaan } \\
\text { pembelajaran } \\
\text { matematika } \\
\text { oleh siswa }\end{array}$ & 94,74 & $\mathrm{ST}$ & 88,89 & $\mathrm{ST}$ \\
\hline
\end{tabular}

Keterangan:

$$
\begin{array}{ll}
\mathrm{X} & =\text { Kelas Eksperimen } \\
\mathrm{Y} & =\text { Kelas Kontrol } \\
\mathrm{ST} & =\text { Sangat Tinggi }
\end{array}
$$

Sehingga dapat disimpulkan bahwa selama proses pembelajaran menggunakan model Think-Talk-Write dan model Think-Pair-Share tingkat ketercapaian pembelajaran tergolong sangat tinggi. 
Jurnal Derivat Volume 3 No. 1 juli 2016 (ISSN: 2407 - 3792)

Halaman 49 - 56

Analisis Respon Siswa dengan Model

Think-Talk-Write dan Model Think-

\section{Pair-Share}

Angket respon siswa yang diisi oleh siswa digunakan untuk mengetahui respon siswa terhadap pembelajaran matematika yang terlaksana di kelas eksperimen dan di kelas kontrol. Data statistik hasil angket respon siswa dengan model Think-TalkWrite dan model Think-Pair-Share adalah sebagai berikut.

Tabel 4. Hasil Angket Respon Siswa terhadap Pembelajaran Matematika

\begin{tabular}{|l|c|c|c|c|}
\hline $\begin{array}{c}\text { Presentase } \\
(\%)\end{array}$ & $\mathrm{X}$ & $\begin{array}{c}\text { Kate } \\
\text { gori }\end{array}$ & $\mathrm{Y}$ & $\begin{array}{c}\text { Kate } \\
\text { gori }\end{array}$ \\
\hline $\begin{array}{l}\text { Presentase } \\
\text { angket } \\
\text { respon siswa } \\
\text { terhadap } \\
\text { pembelajaran } \\
\text { matematika }\end{array}$ & 72,25 & $\mathrm{~T}$ & 70,38 & $\mathrm{~T}$ \\
\hline
\end{tabular}

Keterangan:

$$
\begin{array}{ll}
\mathrm{X} & =\text { Kelas Eksperimen } \\
\mathrm{Y} & =\text { Kelas Kontrol } \\
\mathrm{T} & =\text { Tinggi }
\end{array}
$$

Sehingga dapat disimpulkan bahwa presentase angket respon siswa terhadap pembelajaran matematika berkategori tinggi baik di kelas eksperimen maupun di kelas kontrol.

\section{KESIMPULAN}

Berdasarkan penelitian eksperimen yang telah dilaksanakan dapat disimpulkan sebagai berikut.

1. Model pembelajaran kooperatif tipe Think Talk Write (TTW) sama efektifnya dengan model pembelajaran kooperatif tipe Think Pair Share (TPS) dilihat dari kemampuan komunikasi matematika siswa dengan $t_{o b s}=$ $1,333<t_{(0,05)(54)}=2,005$.

2. Tingkat keefektifan model pembelajaran kooperatif tipe Think Talk Write (TTW) sebesar 0,30 dengan kategori sedang dan tingkat keefektifan model pembelajaran kooperatif tipe Think Pair Share (TPS) sebesar 0,28 dengan kategori rendah.

3. Model pembelajaran kooperatif tipe Think Talk Write (TTW) sama efektifnya dengan model pembelajaran kooperatif tipe Think Pair Share (TPS) terhadap kemampuan komunikasi matematika siswa karena pembelajaran yang dilakukan pada kedua kelas tersebut sama-sama menggunakan model pembelajaran kooperatif, dimana siswa berperan aktif secara individu dalam diskusi kelompok dan terdapat sintaks yang sama pada kedua model tersebut yaitu pada tahap think.

\section{REFERENSI}

Ahmad Susanto. 2013. Teori Belajar dan Pembelajaran di Sekolah Dasar. Jakarta: Kencana Prenadamedia Group.

Karunia Eka Lestari dan Mokhamad Ridwan Yudhanegara. 2015. Penelitian Pendidikan Matematika. Bandung: PT Refika Aditama. 
Efektivitas Model Pembelajaran Kooperatif Tipe Think Talk Write (TTW)

Terhadap Kemampuan Komunikasi Matematika Siswa Kelas VIII MTs Negeri

Godean

Fety Risdiyati, Sri Endah Mianti, Laela Sagita

Miftahul Huda. 2013. Model-model

Pengajaran dan Pembelajaran

Isu-isu Metodis dan

Paradigmatis. Yogyakarta:

Pustaka Pelajar.

Rosliana Harahap, Izwita Dewi, dan

Sumarno. 2012. "Perbedaan

Peningkatan Kemampuan

Komunikasi dan Koneksi

Matematis Siswa Melalui

Pembelajaran Kontekstual

dengan Kooperatif Tipe STAD di

SMP Al-Washliyah 8 Medan”,

dalam Jurnal Pendidikan

Matematika PARADIKMA, Vol 5

Nomor 2 , hal 186-204.

Sugiyono. 2009. Metode Penelitian

Kuantitatif, Kualitatif dan $R \& D$.

Bandung: Alfabeta.

Utari Sumarmo. 2005. Pembelajaran

Matematika untuk Mendukung

Pelaksanaan Kurikulum Tahun

2002 Sekolah Menengah.

Makalah Seminar Pendidikan

Matematika di FMIPA

Universitas Negeri Gorontalo,

Gorontalo. 